\title{
Blue Nile Runoff Sensitivity to Climate Change
}

\author{
Rizwan Nawaz ${ }^{* 1}$, Timothy Bellerby ${ }^{2}$, Mohamed Sayed $^{3}$ and Mohamed Elshamy ${ }^{4}$ \\ ${ }^{1}$ HydroRisk Ltd, Leeds University Union, Lifton Place, Leeds, LS2 9JT, UK \\ ${ }^{2}$ Department of Geography, University of Hull, Hull, HU6 7RX, UK \\ ${ }^{3}$ Eastern Nile Technical Regional Office, P.O. Box 27173-1000, Adis Ababa, Ethiopia \\ ${ }^{4}$ Nile Forecast Center, Ministry of Water Resources and Irrigation, Giza 12666, Egypt
}

\begin{abstract}
This study describes implementation of hydrological climate change impact assessment tool utilising a combination of statistical spatiotemporal downscaling and an operational hydrological model known as the Nile Forecasting System. A spatial rainfall generator was used to produce high-resolution (daily, $20 \mathrm{~km}$ ) gridded rainfall data required by the distributed hydrological model from monthly GCM outputs. The combined system was used to assess the sensitivity of upper Blue Nile flows at Diem flow gauging station to changes in future rainfall during the June-September rainy season based on output from three GCMs. The assessment also incorporated future evapotranspiration changes over the basin. The climate change scenarios derived in this study were broadly in line with other studies, with the majority of scenarios indicating wetter conditions in the future. Translating the impacts into runoff in the basin showed increased future mean flows, although these would be offset to some degree by rising evapotranspiration. Impacts on extreme runoff indicated the possibility of more severe floods in future. These are likely to be exacerbated by land-use changes including overgrazing, deforestation, and improper farming practices. Blue Nile basin flood managers therefore need to continue to prepare for the possibility of more frequent floods by adopting a range of measures to minimise loss of life and guard against other flood damage.
\end{abstract}

Keywords: Blue nile, climate change, hydrology, runoff, downscaling, evapotranspiration.

\section{INTRODUCTION}

Developing countries, particularly those in Africa are likely to be especially vulnerable to climate change as recurrent floods and droughts continue to bring misery to millions in Africa [1]. The prolonged drought in the Greater Horn of Africa (GHA) culminating in 2005 [2] affected 11 million people and was considered the worst in a decade. This was immediately followed in August 2006 by some of the most severe flooding seen in the region which was said to be the worst in 50 years. It is likely that more extreme events like these will be observed more frequently in future as a result of global warming [3].

In an attempt to understand climatic shifts in Africa, [4] studied both annual temperature and precipitation anomalies from the turn of the $20^{\text {th }}$ Century. They noted that temperature increased at a rate of $0.5^{\circ} \mathrm{C} /$ century, which is slightly less than the global average of $0.6^{\circ} \mathrm{C} /$ century determined by the Intergovernmental Panel on Climate Change (IPCC) [5]. They also found that the Sahel had become drier whilst East Africa showed evidence of long-term wetting [4]. Similar findings are also reported in more recent work by $[6,7])$ and the IPCC [5]. For the Ethiopian Highland region in East Africa, [6] reported a slightly increasing trend in rainfall observed between 1905-1965 followed by a prolonged decline

\footnotetext{
*Address correspondence to this author at the HydroRisk Ltd, Leeds University Union, Lifton Place, Leeds, LS2 9JT, UK; Tel: +44(0)7894539052; Fax: +44(0)1132405968; E-mail: r.nawaz@hydrorisk.com
}

in rainfall reaching its minimum in 1984 , and then recovering significantly during the 1990s. Rainfall patterns in Ethiopia since 1960 for June-September were examined by [7] who also reported a general trend towards wetter conditions.

Given the likelihood of future climatic extremes in the region, a number of studies have been carried out over the years to assess the impacts on the major river system in East Africa - the Nile ([6] provides an extensive review). Due to data limitations, the majority of Nile climate impacts studies to date have adopted the standard mean delta change approach. In this method, the mean changes in monthly climate are determined from General Circulation Model (GCM) output and applied to current hydrometric data to drive a rainfall-runoff model to produce runoff changes. The majority of rainfall-runoff models employed to date for the impacts assessment have been simple lumped conceptual models (e.g. $[8,9])$.

In this study, a climate change impact assessment was carried out for the Blue Nile Basin which contributes a significant flow to the main Nile. Several of the limitations of previous investigations were overcome by developing a statistical downscaling model to drive a fully-distributed physically based operational hydrological model used by the Nile Forecasting Centre, Cairo (NFS; [10]). Development of the downscaling model was required to bridge the gap between the rather coarse resolution of standard GCM outputs $(\sim 250 \mathrm{~km}$ and monthly time-step) and the fine spatiotemporal resolution required to drive the NFS $(20 \mathrm{~km}$ and daily time-step). The downscaling model was based on a 
weather generator approach also commonly referred to as spatio-temporal disaggregation methods [11]. The rainfall generator can be considered a multidimensional model able to characterise the rainfall phenomena at every point over the area of interest [12]. For each sequence of monthly GCM outputs, the generator is able to create multiple sequences of daily rainfall fields, each of which remains consistent with the GCM input but contains a random element that enables the ensemble to map out the range of downscaling-related uncertainty (which incorporates some aspects of GCM uncertainty). Ensemble runs of the hydrological model then enable a quantitative assessment of hydrological impacts and their associated precipitation-related uncertainties.

Likely changes in runoff from the current baseline period until 2100 were determined using output from three GCMs forced with two IPCC SRES greenhouse gas emissions scenarios [13]. The GCM output was downscaled to drive the NFS which enabled an assessment of the impacts of climate change on both the mean flow and the flood extremes from June to September; the main rainy season in the region [14].

\section{BLUE NILE DATA \& STUDY AREA}

The Nile and its tributaries provide water for irrigation and hydropower generation to more than 100 million people in the ten countries which share the Nile Basin [15]. The Nile proper is comprised of what are termed the 'White' and 'Blue' Nile. The origins of the White Nile are in deep central Africa, as far south as southern Rwanda. The river flows north through Tanzania, Lake Victoria, Uganda and into
Southern Sudan. The Blue Nile flows about $1,400 \mathrm{~km}$ to the Sudanese capital Khartoum from Lake Tana 1,800 meters above sea level in the Ethiopian Mountains. Both rivers merge near Khartoum, becoming the Nile proper. Given the dependency of millions on the Nile, significant changes in the timing and magnitude of the annual flood could have severe consequences.

The area of the Blue Nile River Basin at Diem river gauging station (see Fig. 1) at the Sudanese Ethiopian border (termed the upper Blue Nile Basin) is approximately 176,000 $\mathrm{km}^{2}$ which is well over twice the size of Ireland. [16] describes the climate of the region as 'tropical highland monsoon' with one rainy season between June and September. The seasonal rainfall distribution is driven by the north-south movement of the inter-tropical convergence zone (ITCZ). During June-September, moist air masses are driven from the Atlantic and Indian Oceans whilst the ITCZ shifts southwards during the rest of the year to provide generally dry conditions. In general, the southern part of the basin is wetter than the western and the northern parts [16]. The main rainy season from June-September leads to a highly seasonal flood regime with $80 \%$ of annual discharge occurring between July and October [17]. Average annual temperature in the region is $20.8^{\circ} \mathrm{C}$ with the diurnal range exceeding the seasonal range [16].

The upper Blue Nile Basin contributes about $50 \%$ of the total annual flow component of the main Nile and is the largest river basin in Ethiopia in terms of volume [17]. The river drains a major part of the central and south-western Ethio-

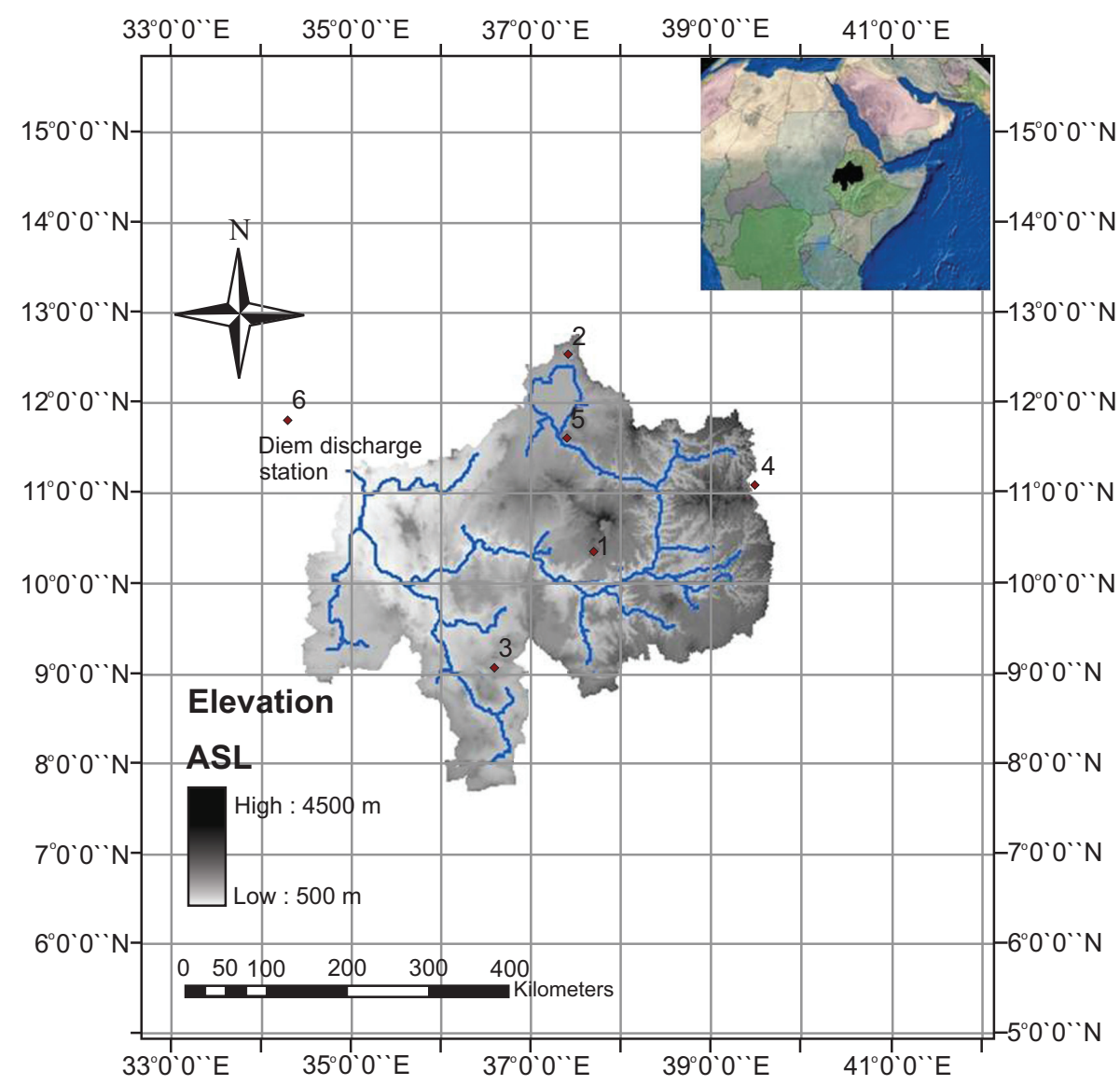

Fig. (1). The upper Blue Nile Basin and location of rainfall stations and Diem flow gauging station ((1) Debre-Markos; (2) Gonder; (3) Nekemte; (4) Kembolcha; (5) Bahar Dar; (6) Roseires)). 
pian highlands [17], with a smaller part of its basin subject to storage in Lake Tana, the largest lake in Ethiopia and the third largest within the Nile Basin [16].

\subsection{Data}

Rainfall data over a ten year period (1992-2001) were available for only six sites within the upper Blue Nile Basin (Fig. 1). Although data from up to eleven different rain gauge sites have been used by previous investigators (e.g. see [17]), a requirement of the current study was access to daily rainfall data which proved difficult to acquire with good spatial coverage. It was decided not to supplement the gauge data with METEOSAT data to avoid introducing further uncertainties into the climate impacts assessment.

A review of rainfall data was undertaken prior to use. It was found that a comprehensive data quality control had been carried out for rainfall data prior to 1995 by [18]. A data review carried out as part of the current study for data since 1995 revealed the main source of error to be rainfall readings of $99.0 \mathrm{~mm}$. After applying various consistency checks such as analysis of Cold Cloud Duration (CCD) data for the relevant day, the data were considered missing. A range of methods are available for infilling missing data (see $[19,20])$ and in this study, Ordinary Kriging [21] was applied. This was shown by [19] to be a robust technique for infilling missing rainfall data in Florida.
Annual rainfall totals for the six stations (see Fig. 1), along with their World Meteorological Organisation ID, longitude, latitude and elevation are provided in Table 1. A monthly breakdown of rainfall (see Fig. 2) shows its confinement to a single season (June-September) with higher values generally observed on higher ground. The average annual rainfall for the catchment upstream of Roseires reservoir is about $1600 \mathrm{~mm}$. It increases, from about $1000 \mathrm{~mm}$ near the Sudan border to about 1400-1800 mm over parts of the upper basin, especially below Lake Tana, and above $1800 \mathrm{~mm}$ in the south, near Nekemte station. It should be noted that rain gauge coverage is far from ideal and fails to meet minimum World Meteorological Organisation (WMO) standards, which requires at least one station over every $200 \mathrm{~km}^{2}$. However this is a common problem in developing countries.

Mean monthly potential evapotranspiration (PET) data interpolated to a $0.20^{\circ}$ resolution grid were available within the NFS database for the Blue Nile basin [10]. The source or averaging period of this data cannot be traced from the available documentation [10]. However, comparisons of the gridded annual potential evapotranspiration data within the NFS with reference crop evapotranspiration $\left(\mathrm{ET}_{\mathrm{o}}\right)$ data from the FAO CLIMWAT database [22] revealed close resemblance [23]. This would indicate short green grass of uniform height as crop type in estimation of the PET using the FAO Penman-Monteith equation [24]. The variability of different

Table 1. Rainfall Station Information for Upper Blue Nile Basin

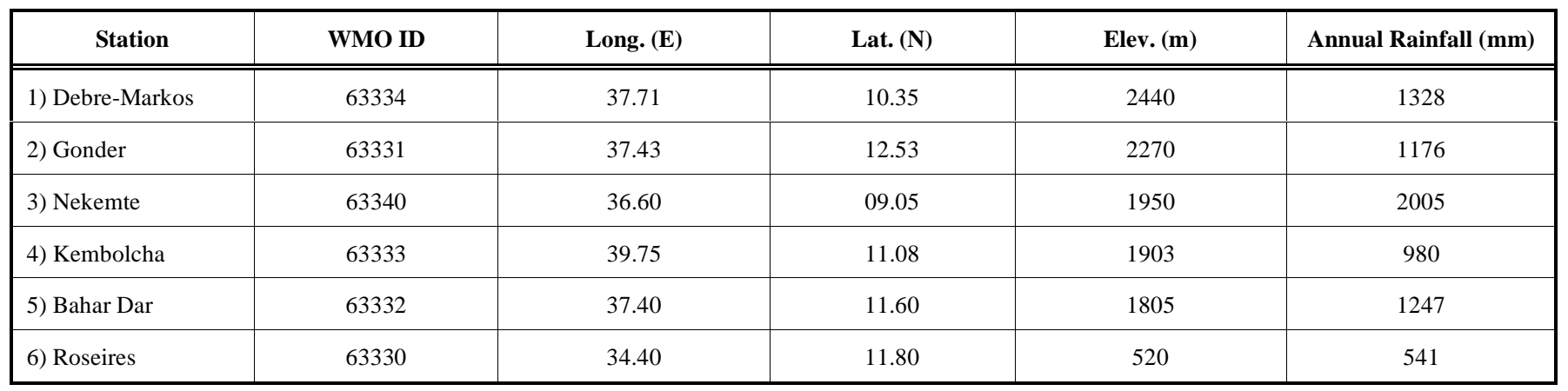

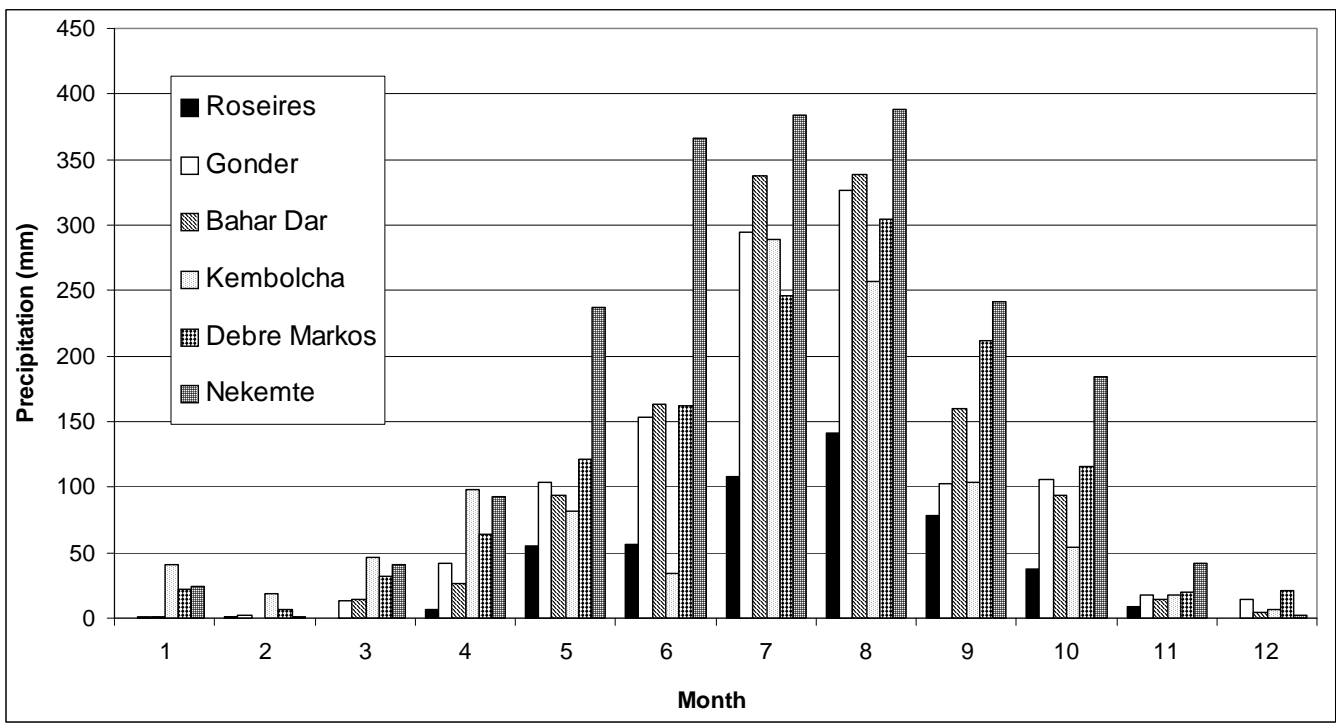

Fig. (2). Observed rainfall data over upper Blue Nile basin (1992-2001). 
years is not considered and the daily values were simply deduced by dividing the monthly total (for each pixel) by the number of days in a month. These data were deemed adequate for the study given that inter-annual variability in potential evapotranspiration is considered small compared to rainfall variability [23].

Daily flow values at Diem gauging station were available for the study. The complete record spanning 1966-2001 was available although only the shorter record coinciding with available daily rainfall data (spanning 1992-2001) was used for model calibrations. Blue Nile average monthly flow at Diem from 1966-2001 (Fig. 3) varies from less than $200 \mathrm{~m}^{3} / \mathrm{s}$ prior to May to approximately $5,500 \mathrm{~m}^{3} / \mathrm{s}$ during August (annual average value of $3600 \mathrm{~m}^{3} / \mathrm{s}$ ). Annual average, maximum and minimum daily flow information is also provided (Fig. 4) and shows the highest peak flows observed in 1969 and $1994\left(10,500 \mathrm{~m}^{3} / \mathrm{s} \& 10,400 \mathrm{~m}^{3} / \mathrm{s}\right)$ and the lowest peak value in $1986\left(5,300 \mathrm{~m}^{3} / \mathrm{s}\right)$. Flows exceeded 5\% (Q5) and 1\% (Q1) of the time have been evaluated as $8,700 \mathrm{~m}^{3} / \mathrm{s}$ and $10,500 \mathrm{~m}^{3} / \mathrm{s}$, respectively. The variation in average flows follows a similar pattern to the peak flows whilst relatively little inter-annual variability is observed in the minimum flow record.

\section{METHODOLOGY}

The climate impact assessment for the upper Blue Nile basin comprised five stages:

(i) Gather historical hydroclimatic data;

(ii) Evaluate performance of several GCMs on the basis of their ability in simulating current climate;

(iii) Gather GCM monthly baseline rainfall and temperature data;

(iv) Downscale GCM output using statistical down-

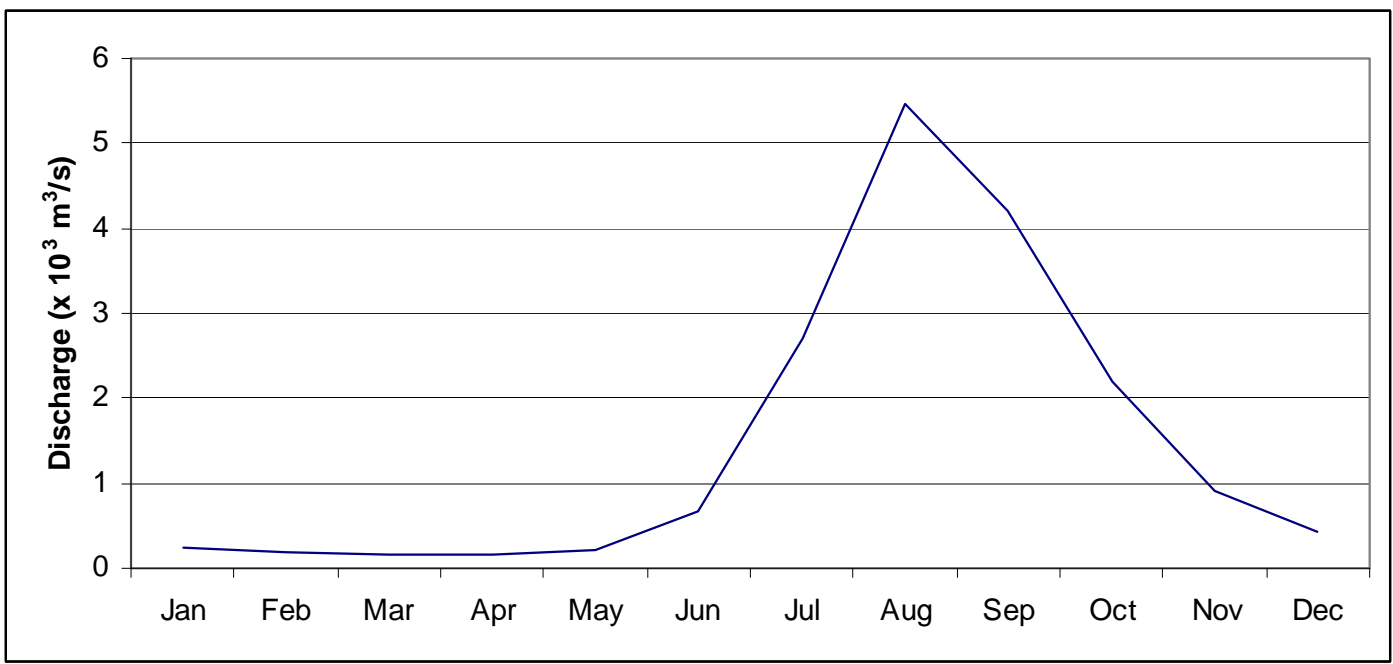

Fig. (3). Upper Blue Nile observed monthly flow at Diem station (Based on 35 years data spanning 1966-2001).

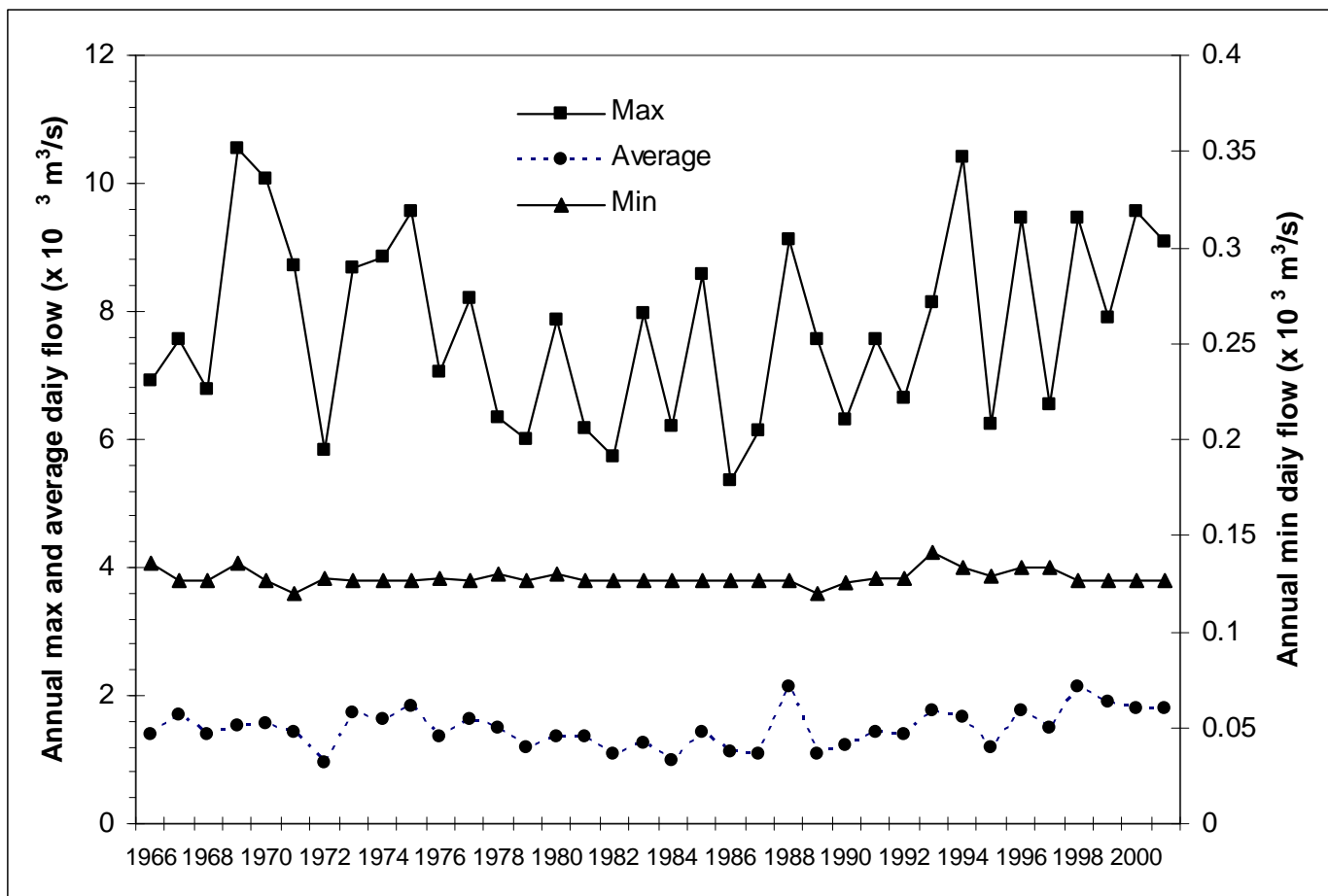

Fig. (4). Blue Nile annual maximum, average and minimum daily flows at Diem station. 
scaling model to produce multiple sequences of rainfall corresponding to baseline and future periods;

(v) Feed rainfall sequences into the NFS to determine changes in future flow changes.

\subsection{Climate Change Scenarios}

In accordance with IPCC guidelines [25] it was decided to use climate change scenarios based on several GCMs allowing the effects of GCM uncertainties to be explored. Selection of GCMs was based on how well the observed baseline rainfall (1992-2001) over the June-September period was simulated and six GCMs were tested for their adequacy. A comparison of GCM and observed rainfall monthly averages and standard deviation revealed very large errors in some GCMs (with relative errors exceeding 150\%) which were removed from the selection and this left the following three GCMs (i) CGCM2 (The Canadian Climate Modelling Centre), (ii) ECHAM4 (Max Planck Institute for Meteorology, Hamburg) and (iii) HadCM3 (UK Hadley Centre). Although output from the third generation atmosphere-ocean coupled Canadian model (CGCM3) is now available the IPCC Data Distribution Centre, this was not the case at the time.

A comparison of GCM simulated rainfall extracted at the six rainfall station point locations (using linear interpolation) within the Blue Nile basin is provided in Table 2 for the main rainy season during June-September. It can be seen that all three GCMs are under-estimating the rainy season rainfall at all stations except Roseires. [5] provide several reasons for differences between GCM simulated and observed climate in Africa including poor model replication of natural climate variability, the absence of dynamic land-cover/atmosphere feedback processes and the absence of any representation of changing atmospheric dust aerosol concentration.

In regard to the inter-model differences in rainfall for the same point locations, a number of factors are contributing and these include differences in horizontal and vertical resolution, differences in the representation of sub-grid physical process, (e.g. cloud formation), model numerical schemes, and feedback mechanisms. Given that sub-grid processes are reported to be the greatest source of errors in GCMs [26] then different representations of these processes are most likely responsible for the differences in GCM output. To explore the effects of future greenhouse gas (GHG) emis- sions uncertainties, two GHG emissions scenarios for forcing the GCMs were considered; the SRES A2 and B2. The scenarios make different assumptions about future global socioeconomic conditions. The A2, with a high climate sensitivity $\left(4.5^{\circ} \mathrm{C}\right)$ assumes higher $\mathrm{GHG}$ emissions than the B2 scenario (a medium climate sensitivity of $2.5^{\circ} \mathrm{C}$ ), especially after 2050, when emissions under B2 scenario are expected to stabilise. Further GHG emissions scenarios were not considered due to study time limitations. Only the GHG forced GCM output was used rather than including the effects of sulphur dioxide and sulphate aerosols.

\subsection{Downscaling}

A variety of methodologies have been developed for downscaling coarse-resolution GCM outputs and other rainfall data to the finer spatiotemporal resolution for hydrological applications (see [27]). For this application, a statistical downscaling approach most clearly matched the data and computational resource requirements. Statistical downscaling is based on the assumption that GCMs adequately simulate regional-scale atmospheric processes (e.g. mean sea-level pressure, geopotential height, humidity) and involves the development of quantitative relationships between regionalscale atmospheric predictor variables and the local statistics of fine-scale meteorological predictand variables such as rainfall over a baseline period. A widely recognised limitation of this method lies in the assumption that the linkage established between the predictor-predictand variables for current climate remains valid in the future. There is however, now some evidence to indicate that the statistical linkages seem to be robust and consistent when sound predictors with a physical basis are used to drive the local predictands in the models (see [28, 29]).

If the final product of the downscaling procedure consists of precipitation fields, rather than discrete precipitation time series, then it is necessary to model the spatial and temporal structure of the precipitation field in addition to its point statistics. These data may then be used to drive a spatial stochastic rainfall generator capable of creating sequences of fine-resolution gridded rainfall fields.

The selection of appropriate predictors is crucial to a climate impact assessment. In many statistical downscaling studies, predictor variables based on atmospheric moisture conditions and large-scale atmospheric circulation patterns are often selected. However, deciding on suitable predictors

Table 2. Comparison of GCM Simulated Rainfall and Observed Rainfall at Six Stations within the Blue Nile Basin (1992-2001)

\begin{tabular}{|l|c|c|c|c|c|c|c|}
\hline \multirow{2}{*}{ Rainfall Station } & \multicolumn{3}{|c|}{ Total Rainfall During June-September (mm) } & \multicolumn{3}{c|}{ Percentage Difference } \\
\cline { 2 - 8 } & Observed & HADCM & CGCM & ECHAM & HADCM & CGCM & ECHAM \\
\hline \hline Debre Markos & 924 & 552 & 610 & 570 & -40 & -34 \\
\hline Gonder & 877 & 295 & 675 & 470 & -66 & -23 & -46 \\
\hline Nekemte & 1379 & 744 & 1048 & 725 & -46 & -24 & -47 \\
\hline Kembolcha & 615 & 321 & 449 & 297 & -48 & -52 \\
\hline Bahar Dar & 999 & 488 & 959 & 508 & -51 & -4 & -49 \\
\hline Roseires & 383 & 512 & 666 & 534 & 34 & 74 \\
\hline
\end{tabular}


is not so straightforward and the climate change effects may depend significantly on predictor choice. For example, [30] demonstrated that projection of future change in mean rainfall and extreme events may change significantly depending on whether humidity is included as a predictor variable.

Different GCMs may be expected to display different performances with respect to their various output variables and the selection of optimal variable sets may have to be performed separately for each GCM. In order to create a more uniform procedure, implementable by hydrological impact assessors rather than experienced climatologists, it was decided to use GCM precipitation as the sole predictor variable. This is different to the common practice of using re-analysis data but is similar to the approach adopted by $[31,32]$ who noted that the rainfall predictor outperformed other commonly adopted predictors such as 1000 -hPa geopotential height.

Standard GCM runs are designed to reproduce climate variability, rather than simulating observed weather patterns and it is not possible to match GCM timelines directly to sequences of observed data. One possible solution to this difficulty is to use specialized GCM runs forced to observed Sea Surface Temperature (SST) data. This approach conflicted with this study's explicit goal of using only readily available GCM data and therefore, an alternative approach based on matching local rainfall frequency distributions was adopted.

Let $\mathrm{R}(\mathrm{y}, \mathrm{m}, \mathrm{i}, \mathrm{j})$ be the rainfall simulated by the GCM for year y, calendar month $\mathrm{m}$ and GCM grid cell $(i, j)$ and $\mathrm{R}^{*}(\mathrm{y}, \mathrm{m}, \mathrm{i}, \mathrm{j})$ be the equivalent observation. As noted above, unforced GCM outputs are not designed to match observed reality, year for year, so in general $\mathrm{R}(\mathrm{y}, \mathrm{m}, \mathrm{i}, \mathrm{j}) \neq \mathrm{R} *(\mathrm{y}, \mathrm{m}, \mathrm{i}, \mathrm{j})$. However, for a dataset spanning a sufficient number of years, the distributions of observed and simulated rainfall values for a given calendar month and grid cell should be similar. Let $R_{1}(m, i, j)$ be smallest simulated rainfall value for month $\mathrm{m}$ in grid box $(\mathrm{i}, \mathrm{j})$ within the baseline dataset, $R_{2}(m, i, j)$ be the second smallest value and so on. Similarly let $\mathrm{R}_{1}{ }^{*}(\mathrm{~m}, \mathrm{i}, \mathrm{j})$ be the smallest monthly rainfall observation for month $\mathrm{m}$ and cell $(\mathrm{i}, \mathrm{j})$ occurring during the baseline period, $\mathrm{R}_{2}{ }^{*}(\mathrm{~m}, \mathrm{i}, \mathrm{j})$ be the second smallest observation and so on. Given the similarity in local frequency distributions, it is not unreasonable to assume that these independently ranked precipitation data should approximately match each other:

$\mathrm{R}_{\mathrm{k}}(\mathrm{m}, \mathrm{i}, \mathrm{j}) \approx \mathrm{R}_{\mathrm{k}} *(\mathrm{~m}, \mathrm{i}, \mathrm{j}), \mathrm{k}=1,2, \ldots$

If each ranked monthly coarse-scale rainfall observation $\mathrm{R}_{\mathrm{k}} *(\mathrm{~m}, \mathrm{i}, \mathrm{j})$ is associated with daily fine-scale rainfall statistics, $S_{\mathrm{k}} *(\mathrm{~m}, \mathrm{i}, \mathrm{j})$, then it is possible to derive a downscaling function, $S=f(R)$, by noting that:

$\mathrm{S}^{*}{ }_{\mathrm{k}}(\mathrm{m}, \mathrm{i}, \mathrm{j}) \approx f\left(\mathrm{R}_{\mathrm{k}}(\mathrm{m}, \mathrm{i}, \mathrm{j})\right)$

If this approximation is assumed to hold for all grid cells $(\mathrm{i}, \mathrm{j})$, months $\mathrm{m}=1 . .12$ and independently ranked years $\mathrm{k}=1,2, \ldots$, then it is possible to derive a single global downscaling function $f$ using a non-linear regression of $\mathrm{S}_{\mathrm{k}}(\mathrm{m}, \mathrm{i}, \mathrm{j})$ against $R_{k}(m, i, j)$ over all $i, j, m$ and $k$. This procedure has some mathematical similarity to the method of histogram matching [33].
Statistical relationships were derived between rainfall from overlying GCM grid box outputs and three statistics of observed data (i) probability of a wet day given a previously wet day $\left(\mathrm{P}_{\mathrm{wW}}\right)$; (ii) probability of a wet day given a previously dry day $\left(\mathrm{P}_{\mathrm{WD}}\right)$ and (iii) daily rainfall amount on a wet day $\left(\mathrm{M}_{\mathrm{RR}}\right)$. The form of the statistical relationships is provided in equations 3-5:

$\mathrm{M}_{\mathrm{RR}}=\mathrm{c}_{1} \mathrm{P}+\alpha$

$\mathrm{P}_{\mathrm{Ww}}=\mathrm{c}_{2} \log _{\mathrm{e}}(\mathrm{P})+\beta$

$\mathrm{P}_{\mathrm{WD}}=\mathrm{c}_{3} \log _{\mathrm{e}}(\mathrm{P})+\gamma$

Where $\alpha, \beta, \gamma$ and $c_{1}, c_{2}, c_{3}$ are regression coefficients and $\mathrm{P}$ is the rainfall simulated by the GCM.

\subsection{Rainfall Field Generation}

The distributed hydrological model (described after the next section) requires gridded precipitation data as input. These rainfall fields were generated using a multidimensional stochastic rainfall generator, the basis for which is the fractionally differenced ARIMA time-series model [34]. The ARIMA model is used to generate a discrete series of values at equidistant points along a set of lines in space; the Turning Bands Method (TBM) [35] is then used to transform these processes into a multidimensional space-time process. The TBM has been described in detail by [36].

The model produces synthetic sequences of daily rainfall reproducing the spatial and temporal structure of historical rainfall. The former was represented using a homogeneous and isotropic exponential model for spatial covariance while the latter was modelled using the parameters; $\mathrm{P}_{\mathrm{Ww}}, \mathrm{P}_{\mathrm{WD}}$ derived above. The assumption of homogeneity and isotropy has also been the basis of rainfall modelling in other studies (e.g. [37]). The rainfall distribution on a rainy day was modelled using a two-parameter gamma distribution scaled by $\mathrm{M}_{\mathrm{RR}}$ which is similar to the approach adopted in other studies (e.g. [38, 39]). The orographic rainfall component associated with the Ethiopian Highlands was modelled using a spatially-varying multiplicative factor derived by comparing the long-term averages of observed and uncorrected simulated rainfall over the baseline period for each $20 \mathrm{~km}$ grid square.

\subsection{Potential Evapotranspiration Scenarios}

To limit the number of GCM variables required for PET estimation, the Thornthwaite formula [40] was used. The formula requires temperature and day length as input. Monthly mean baseline and future temperature simulated by all three GCMs was used to obtain PET changes. Although use of only GCM temperature is quite restrictive in that changes in rainfall would be accompanied by changes in humidity and cloudiness, it was decided to proceed with this simplistic approach since only the relative changes were of interest. These percentage changes were then applied to the observed PET dataset to obtain data at the $20 \mathrm{~km}$ NFS grid. The PET field is somewhat smoother than the precipitation field and no stochastic modelling of PET downscaling uncertainty was performed.

\subsection{Hydrological Modelling}

The NFS $([10,23])$ is a real-time distributed hydrometeorological forecasting system designed for forecasting 
flows at designated key points within the Nile; of major interest is the inflow of the Nile into the High Aswan Dam, Egypt [41]. The core of the NFS is a physically based distributed hydrological model of the Nile basin operating at a daily time-step on a $20 \mathrm{~km}$ grid [42] including soil moisture accounting, hillslope and river routing, lakes, wetlands, and man-made reservoirs within the basin. The NFS requires as input, daily gridded rainfall and potential evapotranspiration. Output information consists of flows at key locations along the Nile including Diem gauging station. The NFS implements a five parameter, two layer water balance model at each $\sim 20 \mathrm{~km}$ each grid cell (Table 3 provides a description of model parameters). The upper soil moisture layer is fed by rainfall and emptied by evapotranspiration, with excess rainfall being transferred to the lower soil moisture layer upon upper layer saturation. Unmet potential evapotranspiration is taken from the lower layer when the maximum upper-layer soil moisture deficit is reached. The lower soil moisture layer is further emptied by surface and subsurface flow that are combined into a single hillslope flow and routed through the mean distance to the channel assumed to flow through each cell using an approximate solution to the kinematic wave equation. A similar kinematic routing model transfers water from each cell to a single neighbouring downstream cell [41, 43].

A previously calibrated version of NFS was used in this study. This has been evaluated by [44], and [45] and found to perform well. [44] evaluated the daily performance and found that it could explain $93 \%$ of the observed daily variance of the Diem flows over the period 1997-2002. [45] evaluated the long-term performance of the NFS and found that it could explain $79 \%$ of the observed monthly variance of Diem flows over the period 1940-1999. Further details of the NFS are provided in [10,41].

\section{RESULTS AND DISCUSSION}

\subsection{Regression Relationships}

Strong correlations were generally observed between the GCM simulated daily rainfall amount and three statistics of the observed rainfall (i) probability of a wet day given a previously wet day $\left(\mathrm{P}_{\mathrm{wW}}\right)$; (ii) probability of a wet day given a previously dry day $\left(\mathrm{P}_{\mathrm{WD}}\right)$ and (iii) daily rainfall amount on a wet day $\left(\mathrm{M}_{\mathrm{RR}}\right)$, as shown in Table 4 . The regression relationships were based on a linear fit for rainfall amount and logarithmic fits for rainfall probabilities (see Equations 3-5).

\subsection{Model Verification}

Verification involved comparing both the downscaled rainfall and the subsequent runoff derived from this, with baseline rainfall and runoff data, respectively.

Observed and simulated modelled rainfall totals (averaged over 50 sequences) at all six rain gauge sites for the rainy season are provided in Table 5. It can be seen that the differences between the observed and downscaled rainfall can range from as low as -1\% (HadCM3 - Debre Markos) to as high as $+30 \%$ (ECHAM - Roseires), and are generally less than $20 \%$. Further verification results, for two rain gauge sites; Debre Markos and Roseires are presented in Figs. (56). Comparisons are provided between four observed and modelled rainfall statistics for the months June-September (1992-2001) including (i) mean rainfall, (ii) rainfall amount on a wet day, (iii) number of wet days in a month and (iv) rainfall probability. Although it is difficult to draw generalisations, the results do reveal that the HadCM3 simulates relatively high rainfall intensity (i.e. rainfall amount on wet days) whilst the lowest modelled rain intensity results from the CGCM. On the basis of results presented in Table $\mathbf{5}$ and Figs. (5-6) (including comparisons between GCM based rainfall with observations at other gauging stations not pre-

Table 3. NFS Water Balance Model Parameter Description

\begin{tabular}{|c|l|c|}
\hline Parameter & \multicolumn{1}{|c|}{ Description } & Units \\
\hline \hline $\mathrm{D}_{\max }$ & Maximum soil moisture deficit in the lower soil layer & $\mathrm{mm}$ \\
\hline $\mathrm{d}_{\max }$ & Maximum soil moisture deficit in the upper soil layer & $\mathrm{mm}$ \\
\hline $\mathrm{K}_{\mathrm{dm}}$ & dmax/Dmax & - \\
\hline $\mathrm{K}_{\mathrm{sm}}$ & Power relating groundwater flow to relative soil moisture content in the lower soil moisture layer & - \\
\hline $\mathrm{K}_{\mathrm{sm}}$ & Infiltration into lower soil moisture layer & - \\
\hline $\mathrm{Q}_{\max }$ & Maximum value of subsurface outflow & $\mathrm{mm} / \mathrm{day}$ \\
\hline
\end{tabular}

Table 4. Correlation Coefficients for GCM Simulated Daily Rainfall and Three Statistics of Observed Rainfall (MR, Pww and $P_{W D}$ are the Mean Rainfall on a Wet Day, Probability of a Wet Day Followed by a Wet Day and Probability of a Wet Day Following a Dry Day, Respectively)

\begin{tabular}{|c|c|c|c|}
\hline $\mathbf{G C M}$ & $\mathbf{M}_{\mathbf{R R}}(\mathbf{m m} / \mathbf{d a y})$ & $\mathbf{P}_{\mathbf{W w}}$ & $\mathbf{P}_{\mathbf{W D}}$ \\
\hline \hline CGCM & 0.81 & 0.94 & 0.85 \\
\hline ECHAM & 0.81 & 0.90 & 0.82 \\
\hline HADCM & 0.82 & 0.89 & 0.78 \\
\hline
\end{tabular}


Table 5. Comparison of Downscaled Rainfall and Observed Rainfall at Six Stations within the Upper Blue Nile Basin (1992-2001)

\begin{tabular}{|c|c|c|c|c|c|c|c|}
\hline Rainfall Station & \multicolumn{4}{|c|}{ Total rainfall during June-September ( $\mathbf{m m})$} & \multicolumn{3}{|c|}{ Percentage Difference } \\
\hline Debre Markos & 924 & 913 & 865 & 833 & -1 & -6 & -10 \\
\hline Gonder & 877 & 805 & 752 & 688 & -8 & -14 & -22 \\
\hline Nekemte & 1379 & 1122 & 1077 & 1113 & -19 & -22 & -19 \\
\hline Bahar Dar & 999 & 939 & 876 & 831 & -6 & -12 & -17 \\
\hline Roseires & 383 & 464 & 488 & 500 & 21 & 27 & 30 \\
\hline
\end{tabular}

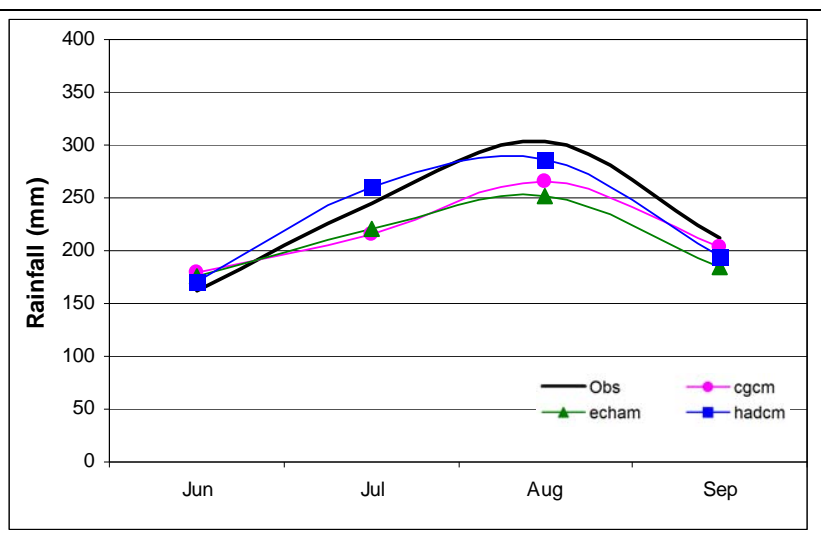

(a) Mean monthly rainfall

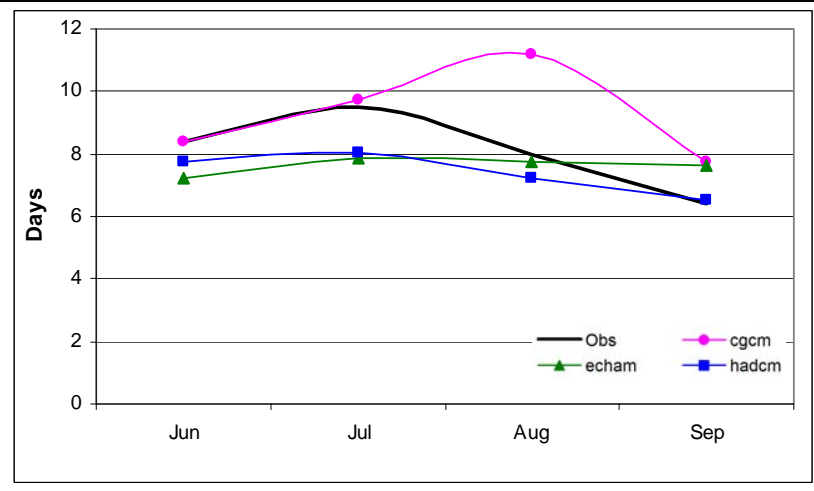

(c) Number of wet days in month

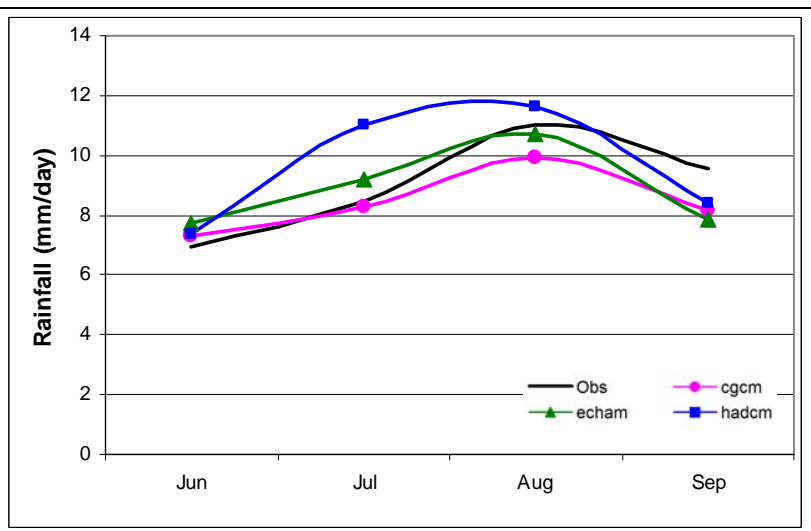

(b) Mean rainfall on wet day

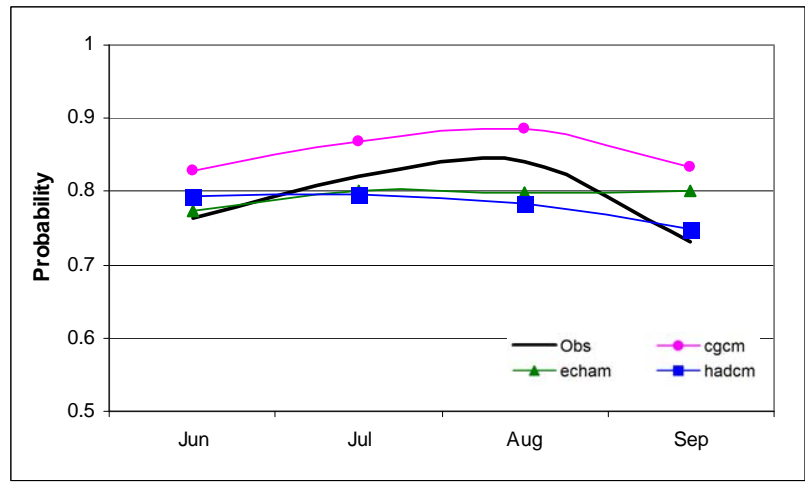

(d) Rainfall probability

Fig. (5). Comparison of downscaled rainfall with observed rainfall statistics at Debre Markos.

sented here), the downscaling model based on the HadCM3 GCM appears to be performing slightly better than the others, especially in simulating mean rainfall and rainfall intensity.

Runoff based on GCM downscaled rainfall (50 sequences) over the baseline period was compared with observations (1992-2001) at Diem gauging station (see Fig. 1). Because of the importance of rainy season flows to water resources planners, the results will focus on the rainy season (June-September). Three performance metrics; mean daily flow and Q5 \& Q1 (daily flow exceeded 5\% \& $1 \%$ of the time, respectively) over the rainy season were adopted, as shown in Fig. (7). 50 sets of Blue Nile flows over the baseline period based on the CGCM2 (C), ECHAM4 (E) and HadCM3 $(\mathrm{H})$ models are shown in the form of box-plots with the corresponding observed value in Fig. (7). Both the mean and Q5 seem to be well simulated by all GCMs. However, this is not the case with Q1 with the simulated flow higher than observed. This indicates that the combined modelling procedure might be generating unrealistically high maximum flows. As was the case with rainfall simulation, it is the HadCM3 based flow that is most adequately reproducing observed flow. 


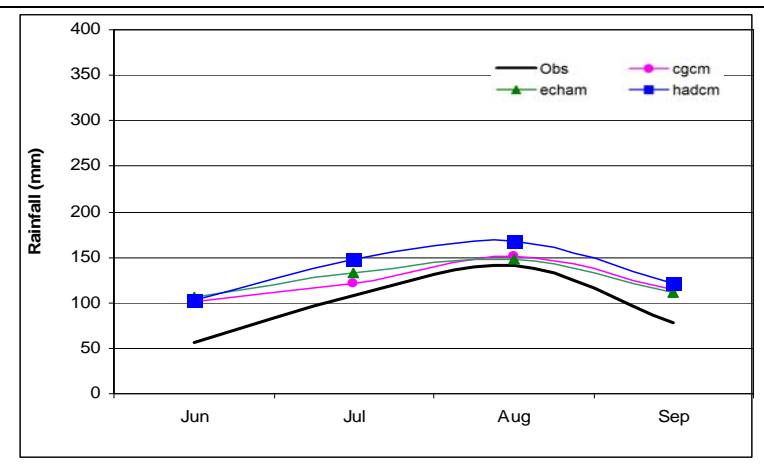

(a) Mean monthly rainfall

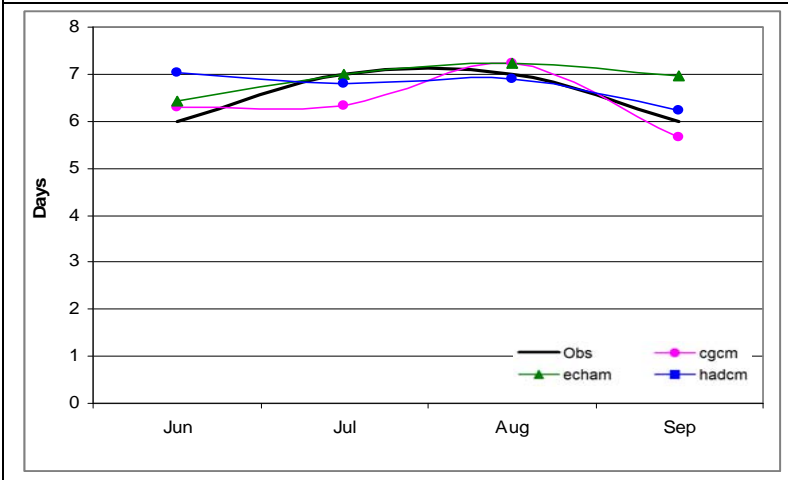

(c) Number of wet days in month

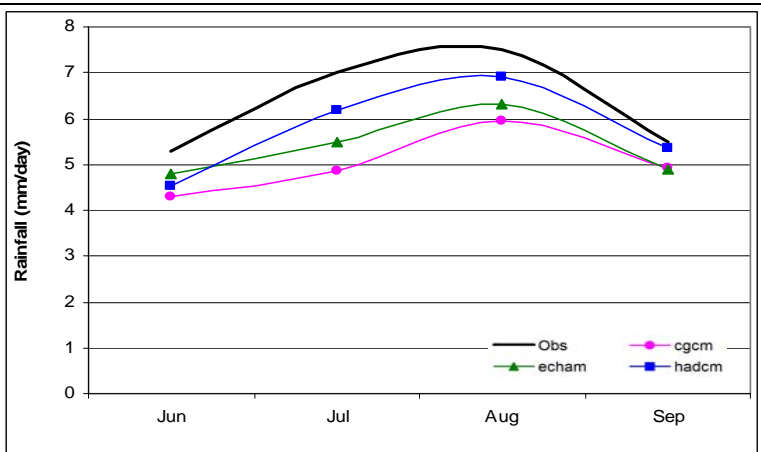

(b) Mean rainfall on wet day

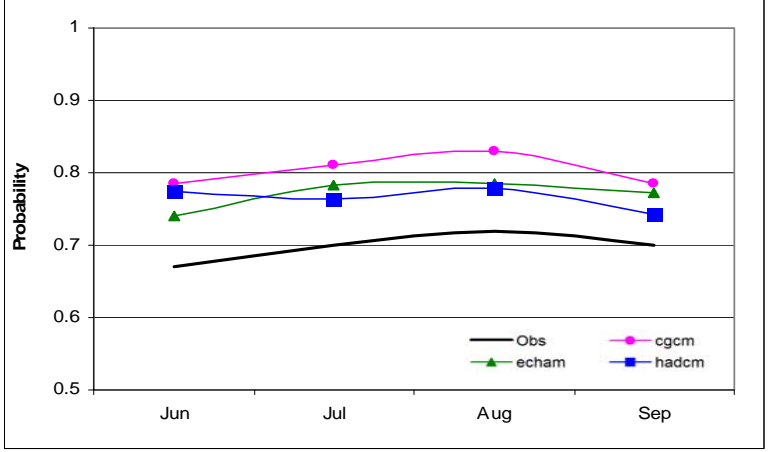

(d) Rainfall probability

Fig. (6). Comparison of downscaled rainfall with observed rainfall statistics at Roseires.

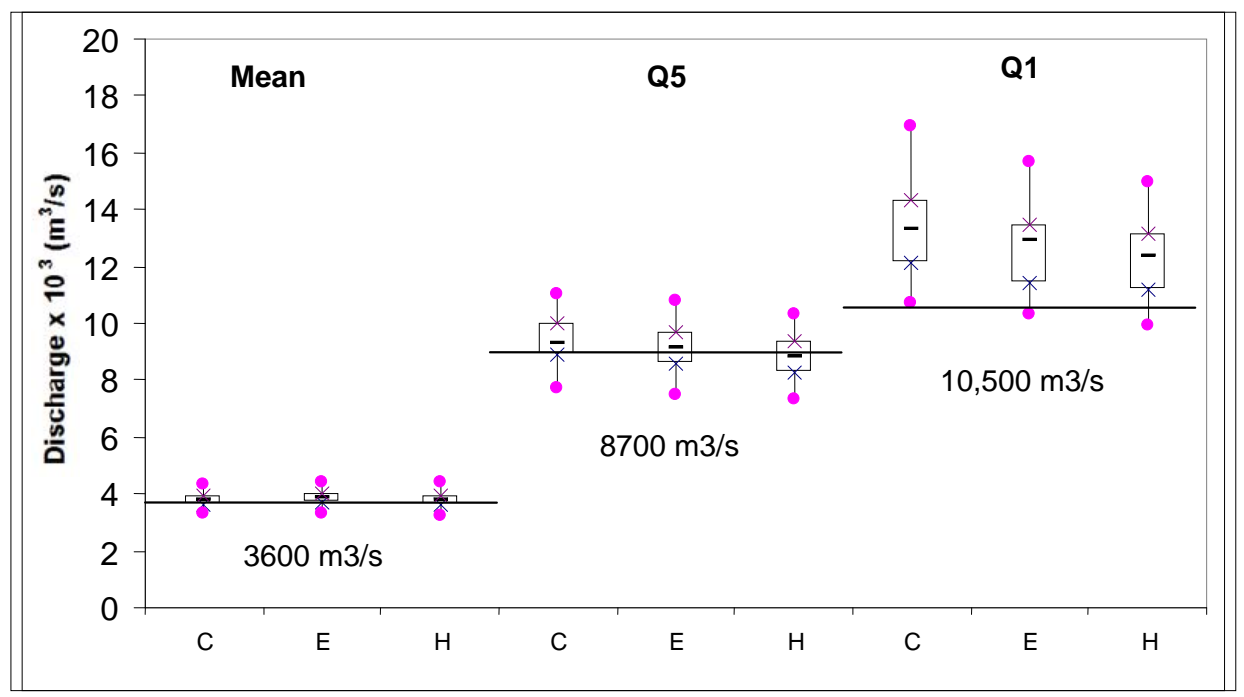

Fig. (7). Observed and simulated flow based on 3 GCMs at Diem station for the rainy season over the baseline period (solid horizontal lines and numbers below box plots indicate observed values).

To explore the effects of future greenhouse gas (GHG) emissions uncertainties, two GHG emissions scenarios for forcing the GCMs were considered; the SRES A2 and B2 [46]. Rainfall simulated by the GCMs was downscaled using the multidimensional stochastic rainfall generator, alongside PET scenarios described earlier to drive the NFS. This enabled an assessment of the impacts of climate change on both mean flow and the flows exceeded $5 \%$ and $1 \%$ of the time during June to September.

Three 30-year future time periods until 2099 were considered; (i) 2010-2039, (ii) 2040-2069 and (iii) 2070-2099 and these will be referred to as the 2020s, 2050s and 2080s. Further acronyms used for presenting the results include use of the initial letter from the GCM name and the initial number from the time-period of interest. For example, $\mathrm{C} 2$ represents CGCM 2020s, H8 represents HadCM3 2080s etc.

\subsection{Rainfall Changes}

The downscaled rainfall scenarios for the rainy season until 2100 are presented in Fig. (8). Changes are shown for three rainfall statistics; (i) mean daily rainfall, (ii) rainfall intensity (rainfall amount on a wet day) and (iii) number of 


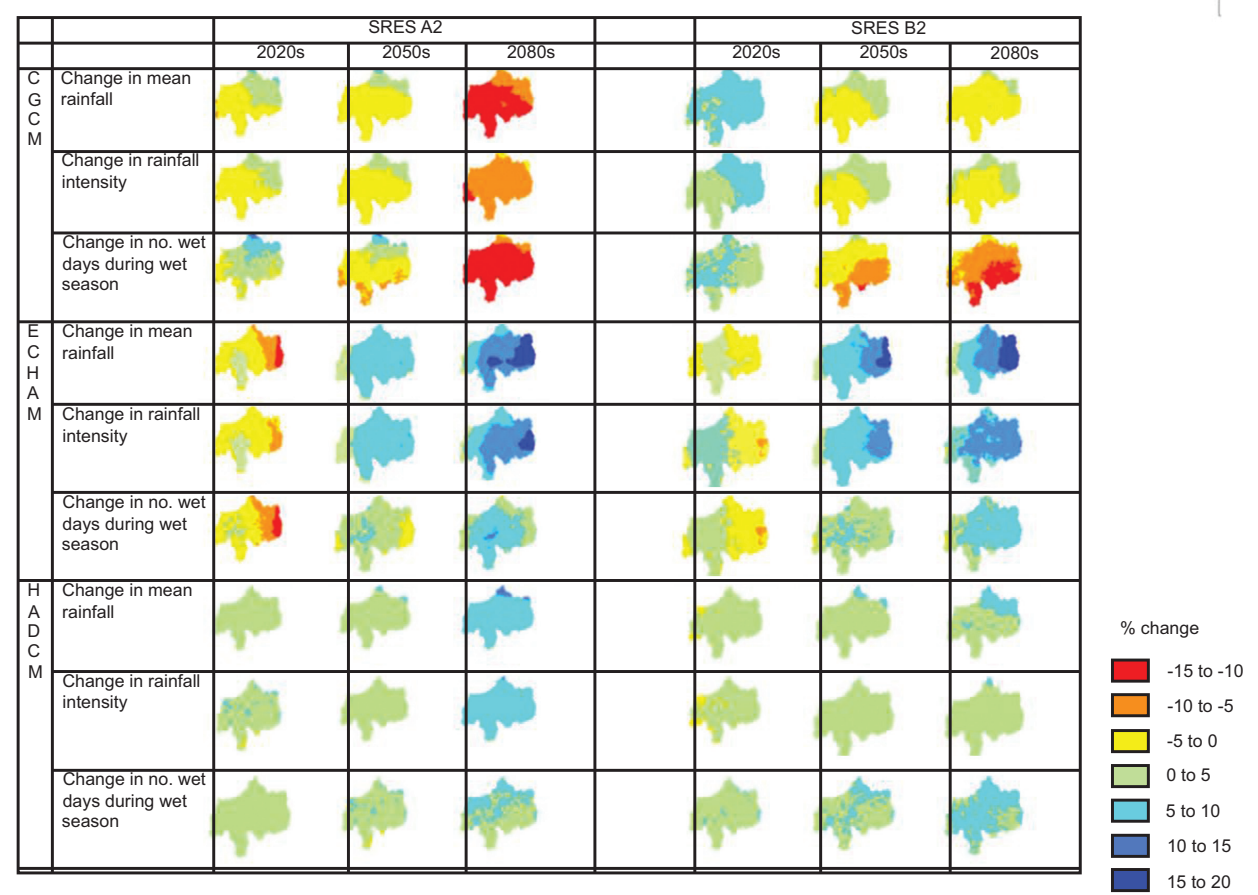

Fig. (8). Percentage change in rainfall over the Blue Nile basin based on three global climate models.

wet days during the rainy season. By the 2020s, the CGCM and HadCM3 models indicate a general wetting pattern whilst the ECHAM indicates less rainfall. In general however, it can be concluded that the HadCM3 and ECHAM models suggest a wetter future whilst the CGCM indicates a drier future. For example, up to $20 \%$ increase in mean rainfall and rainfall intensity is likely in the eastern part of the basin by the 2080s according to ECHAM. In contrast, the CGCM indicates rainfall reductions by up to $15 \%$. Results also show that a much wetter future is likely over much of the eastern portion of the basin by the 2080s according to ECHAM whilst it is the northern part of the basin that is likely to experience wetter conditions in future according to the HadCM3. Changes are generally more pronounced under the A2 emissions scenario since GHG emissions continue to rise by the 2080s whilst under the B2 scenario, they are stabilised at 2050 levels. [46, 47] have also reported similar findings based on output from seven GCMs including the three used in this study. They found the CGCM model was indicating drier conditions, especially for the 2050s and 2080s under both the A2 and B2 emissions scenario for the period June-August. Similarly, in the six GCMs used by [48] to construct climate change scenarios for the Nile basin, results from the first generation atmosphere-ocean coupled models CGCM, ECHAM and HadCM revealed annual changes (from baseline) in rainfall of $-8.8 \%,+23.3 \%$ and $+54.6 \%$, respectively.

Such inter-model differences are likely to be a result of different climate model parameterisations. The climate system includes a variety of physical processes, such as cloud processes, radiative processes and boundary-layer processes, which interact with each other on many temporal and spatial scales. Due to the limited resolutions of the GCMs, many of these processes are not resolved adequately by the model grid and must therefore be parametrized. Differences between parametrizations are an important reason why climate model results differ [49].
Although, rainfall changes according to each scenario are equally likely, it is useful to note that East Africa has experienced a general trend towards wetter conditions in the past. Moreover, the majority of climate change scenarios suggest continuation of this trend with anticipated wetter future conditions [4,50,51]. For example, [4] noted that the JuneAugust period by the 2050s and 2080s (A2 scenario), was likely to become wetter. In the 21 GCMs used by [51] to provide future climate projections for East Africa, 17 indicated wetter future conditions. On the basis of this, it could be argued that greater emphasis needs to be placed on output from the HadCM3 and ECHAM models.

The extent of uncertainties in rainfall changes due to the downscaling carried out in this study have also been quantified and are presented in Fig. (9). Results show the likely range of changes and are based on differences between 50 baseline and future rainfall sequences and are provided for two metrics; mean areal rainy season (June-September) rainfall and mean areal rainfall exceeded $5 \%$ of the time (P5).

\subsection{Potential Evapotranspiration Changes}

Future changes in PET during the rainy season are presented in Fig. (10) for the SRES A2 GHG emissions scenarios. Since the PET was driven largely by temperature, results are indicative of temperature changes. PET is set to rise under all scenarios with the largest increase according to the ECHAM4 model of +15 to $+30 \%$ (2050s) and up to $90 \%$ increase in the northern part of the basin by the 2080s. The CGCM2 model results in more moderate increases of 0 to $+5 \%$ (2050s) to $+15 \%$ to $+30 \%$ (2080s). Projected HadCM3 increases lie between those estimated by the CGCM2 and ECHAM4. It is important to note that in reality, the PET increases might not be as severe as those reported here. This is because extra cloudiness and humidity will be associated with extra rainfall in the future; something ignored by the Thornthwaite formula. If good future cloud cover data (and 

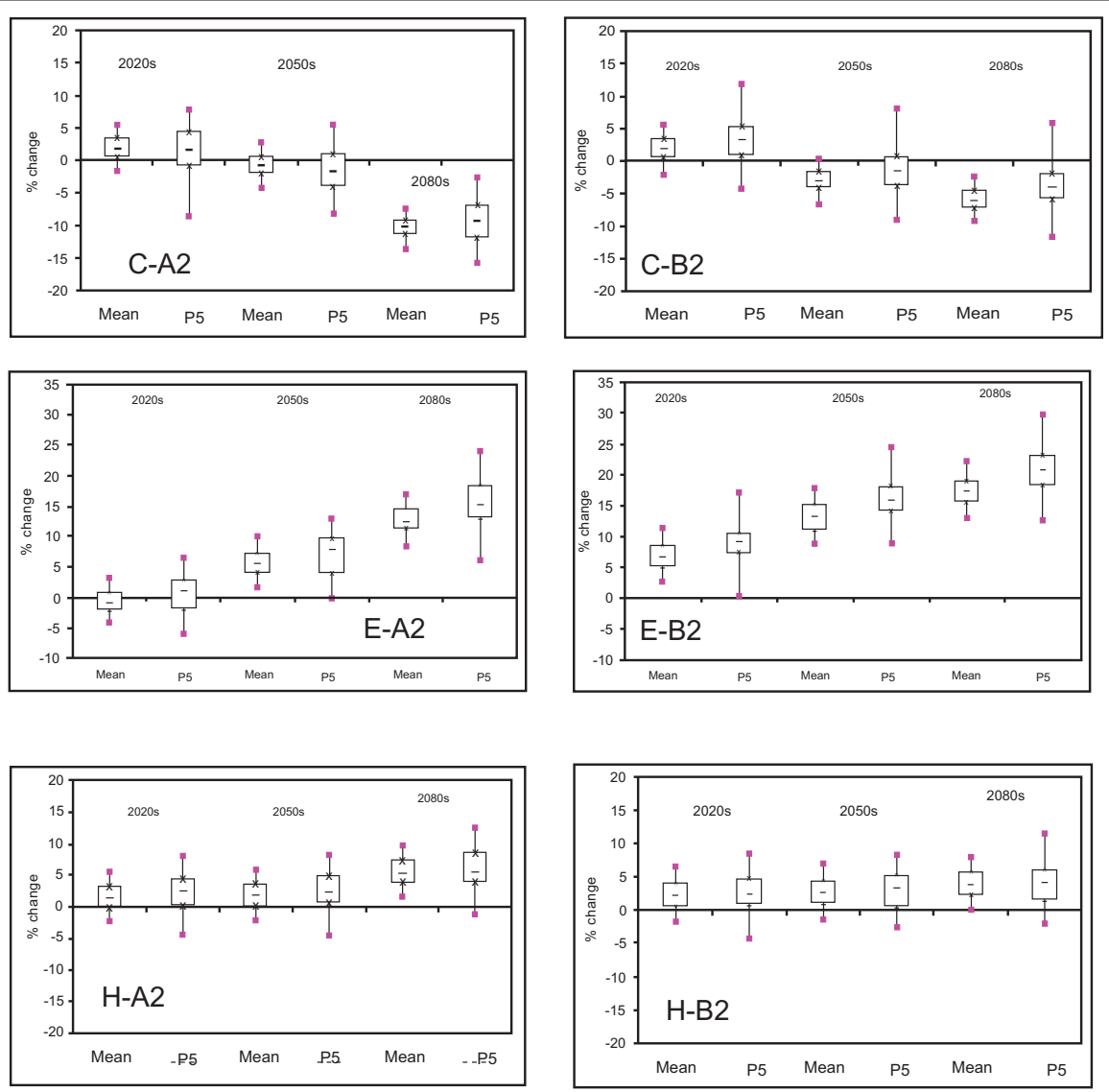

Fig. (9). Percentage change in Blue Nile basin areal rainfall (from baseline) for A2 and B2 GHG emissions scenarios over wet season (JuneSeptember; P5 is the change in areal rainfall exceeded 5\% of the time).

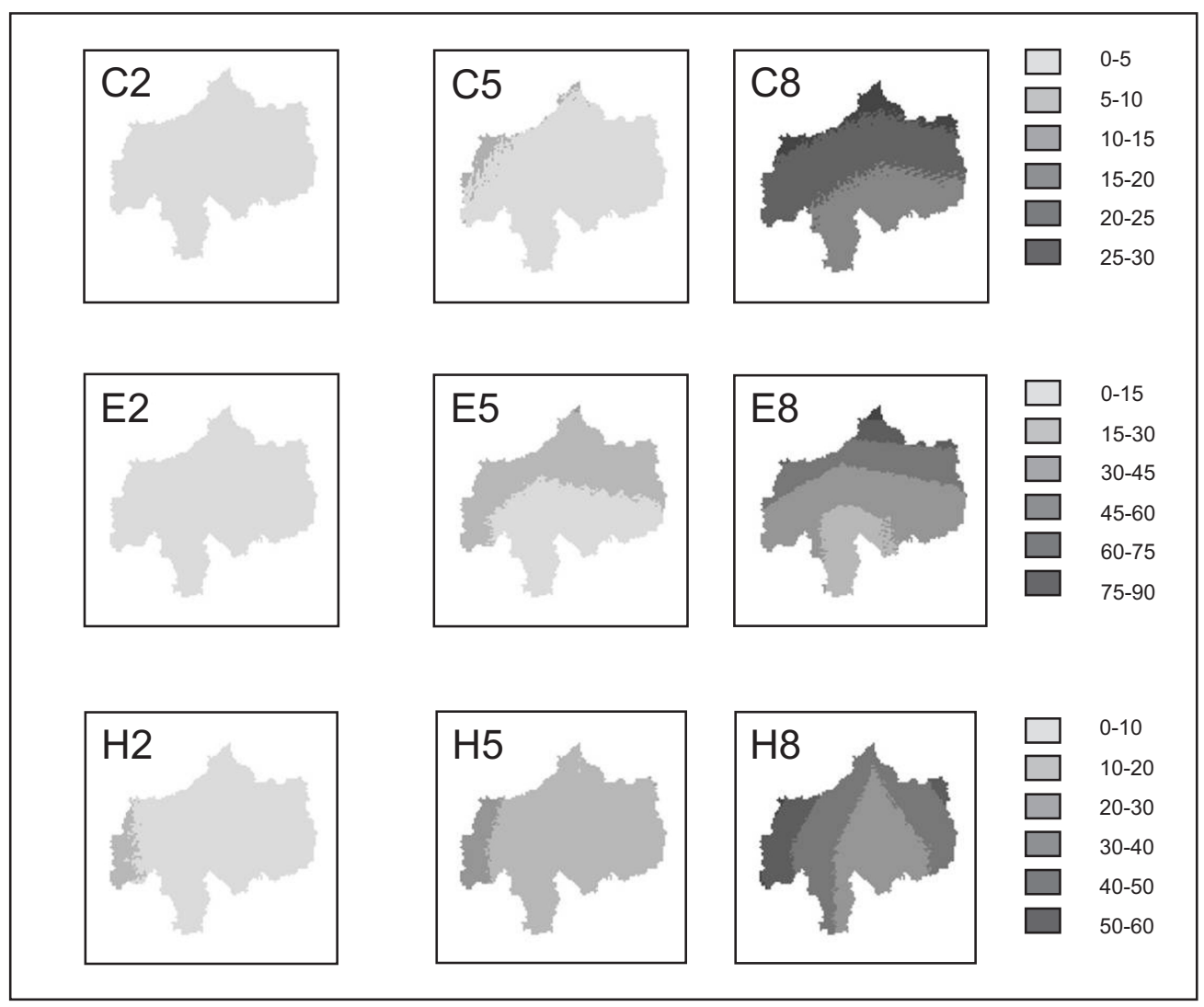

Fig. (10). Wet season PET changes (\% from baseline) SRES A2. 
other data parameters) required for application of any radiation based PET equation were available from GCMs, it would be possible to apply a correction factor in future research to gain a more accurate change in PET.

\subsection{Flow Changes}

Fig. 11 shows the future change (percentage from baseline) in flow at Diem station for the rainy season (JuneSeptember). Changes are presented in a similar format to rainfall changes presented as box-plots earlier. The flow change results also include an additional peak flow metric; Q1 (flow exceeded 1\% of the time).

By considering only the inter-quartile range in the box plots, it can be concluded that some rather significant changes in flow are likely during all three time-periods, which is in contrast to the moderate rainfall changes. The CGCM2 indicates drier conditions driven by the rainfall scenarios. The marked difference between projected flow reductions under the CGCM2 A2 and B2 scenarios for the 2050s is noteworthy. Results highlight the high sensitivity of flow changes to rainfall changes (see rainfall scenarios in Figs. 8 \& 9). Results from HadCM3 suggest that although a wetter future is likely (Fig. 9), flow is set to decrease, especially by the 2080s. This is because increased PET across the basin (Fig. 11) leads to flow reduction even though rainfall increases by a small amount. Although future rainfall is likely to generally increase (substantially in some cases) over the future according to the ECHAM4, flow increases are rather modest (and likely to reduce in some cases) because of the PET increases (Fig. 10).

The full range of likely flow changes (within the interquartile range) including the median changes for the 2050 s and 2080s are summarised in Table 6. The median values in bold indicate that the $\%$ change in mean flow could vary from $-47 \%$ (CGCM A2 2080s) to $+12 \%$ (ECHAM B2 2050s). Similar reductions in Q5 are expected but a greater increase (32\% increase under the ECHAM B2 2050s). To reveal the effects of downscaling uncertainty on the assessed
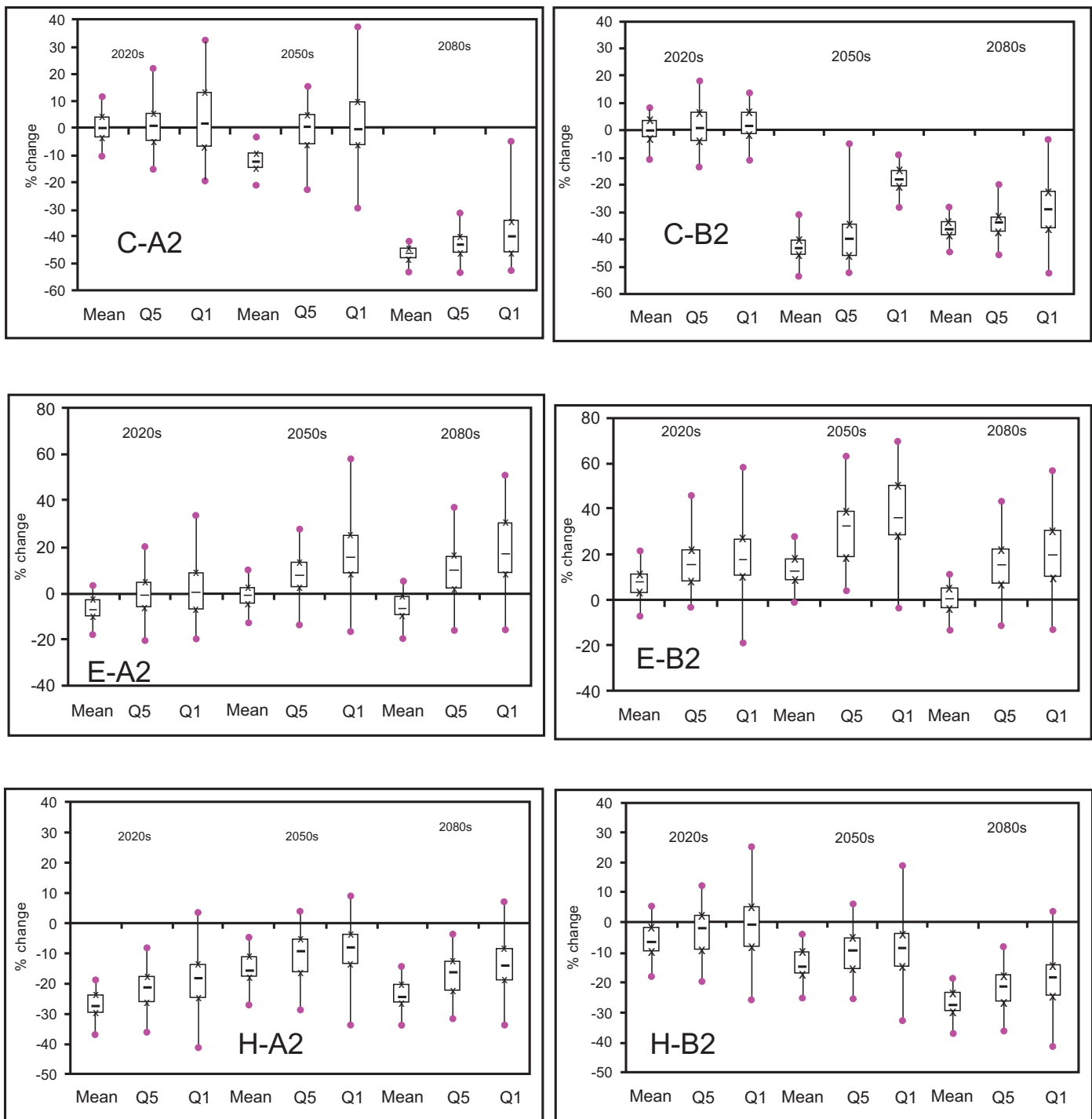

Fig. (11). Percentage change in discharge (from baseline) of Blue Nile flow (at Diem) for A2 and B2 GHG emissions scenarios over wet season (June-September; Q5 and Q1 is the flow exceeded 5\% and 1\% of the time, respectively). 
Table 6. Percentage Change (from Baseline) in Flow During Rainy Season

\begin{tabular}{|c|c|c|c|c|c|c|}
\hline Scenario & \multicolumn{3}{|c|}{$\%$ change in mean flow } & \multicolumn{3}{|c|}{$\%$ change in Q5 (flow exceeded $5 \%$ of the time) } \\
\hline $\mathrm{C} 5$ & -12.5 & -9.0 & -14.6 & 0.1 & 4.9 & -6.3 \\
\hline $\mathrm{C} 8$ & -46.6 & -44.7 & -48.5 & -43.4 & -40.2 & -46.0 \\
\hline E8 & -6.6 & -1.8 & -9.7 & 9.7 & 15.9 & 1.6 \\
\hline H5 & -15.9 & -11.3 & -18.0 & -9.6 & -5.6 & -16.5 \\
\hline $\mathrm{H} 8$ & -24.4 & -20.4 & -26.5 & -16.5 & -12.6 & -22.5 \\
\hline \multicolumn{7}{|l|}{ SRES B2 } \\
\hline E5 & 12.4 & 17.9 & 8.0 & 32.1 & 38.6 & 18.1 \\
\hline E8 & -0.6 & 4.9 & -4.4 & 15.1 & 22.3 & 6.5 \\
\hline H5 & -14.6 & -9.8 & -17.1 & -9.5 & -5.1 & -15.7 \\
\hline H8 & -27.5 & -23.7 & -29.9 & -21.6 & -17.8 & -26.6 \\
\hline
\end{tabular}

C5: CGCM2 2050s; C8:CGCM2 2080s; E5:ECHAM4 2050s; E8:ECHAM2 2080s; H5:HadCM3 2050s; H8:HadCM3 2080s; PC: Percentile.

impacts, we need to examine the full range of results within the inter-quartile range (Table 6). Results show that greater variation in assessed impacts is likely and percentage change in mean flow could vary from $-48.5 \%$ (CGCM2 A2 2080s) to $+18 \%$ (ECHAM B2 2050s). This large variation corresponds to limits within the $75^{\text {th }}$ and $25^{\text {th }}$ percentiles and would be even greater had results been presented in between the $90^{\text {th }}$ and $10^{\text {th }}$ percentiles.

The mean changes reported in this study are in general agreement with what other investigators have noted using the early generation GCMs and IPCC 1992 greenhouse gas emissions scenarios. [52, 53] reported that GCM scenarios provided widely diverging pictures of possible future river flows, from a $30 \%$ increase to a $78 \%$ decrease; larger reductions were likely as is the case in the present study. [8] used output from three GCMs, and termed these the 'wet' case, 'dry' case and composite case which resulted in $+15 \%,-9 \%$ and $+1 \%$ changes in mean annual Blue Nile runoff for 2025 , respectively. [48] noted a range of changes for a doubling of $\mathrm{CO}_{2}$ concentrations; mean annual flow was likely to change by $-19 \%$ (CGCM1), $+41 \%$ (ECHAM1) and $+133 \%$ (HadCM1). What the present study has also highlighted is the larger range of flow changes possible due to climate downscaling uncertainties.

\section{SUMMARY AND CONCLUSIONS}

It is evident that despite advances in climate modelling over the years, there still appears to be disagreement amongst GCMs in simulating future precipitation for a given region. In the case of the Blue Nile, results reported in this study indicate a drier future according to one GCM whilst two others indicate wetter futures. Better consistency is ob- served in temperature changes, which leads to more consistent potential evapotranspiration changes and these are expected to be very large by the 2080s. Based on work reviewed by the IPCC [5], East Africa has experienced an increasingly wetter climate and is likely to become wetter in future according to the majority of climate model simulations. However, it should be noted that the lack of good rain gauge coverage prevents conclusive rainfall trend detection. In time, this should become less of a problem as the availability and accuracy of remotely sensed rainfall data increases. The expectation of wetter futures is consistent with the findings reported in the present study; 13 out of 18 climate change scenarios for three future time periods indicate wetter conditions over the Blue Nile basin.

As expected, future wetter conditions in the basin result in increased average and extreme flows. However, the impact on flow is offset by increasing PET, and in some cases, flow is expected to reduce despite small increases in rainfall. This does require further investigation since a relatively simple approach for PET estimation was adopted that is not able to account for extra cloudiness and humidity associated with increasing rainfall.

Future wetter conditions within the basin could result in severe flood events occurring more frequently and devastating communities, particularly in Khartoum. Something which has been overlooked in this study is the continued impacts of land-use change related to overgrazing, deforestation, and improper farming practices in the Ethiopian highlands. Such practices will inevitably lead to soil erosion, loss of soil fertility and reduced infiltration thus exacerbating the flood problem. Blue Nile basin flood managers therefore need to continue to prepare for such eventualities by adopt- 
ing a range of measures to minimise loss of life and other flood damage.

Whilst the approach adopted in the current study is only able to inform decision-makers about the possible range of impacts, more recent outputs from the climate modelling community may enable the probable range of impacts to be determined in future. The UK Climate Impacts Programme (UKCIP) has pioneered this work and recently published the UKCP09 scenarios [54] which attach likelihood to climate change scenarios.

\section{ACKNOWLEDGEMENTS}

The authors gratefully acknowledge the support of the Dr Bayoumi Attia, Director of the "Lake Nasser Flood and Drought Control" project funded by the Dutch government, Dr Mamdouh Antar and Mr Bakar Badawy of the Nile Forecast Centre, Egyptian Ministry of Water \& Irrigation for allowing access to their datasets and use of the NFS. Thanks are also due to Dr Jaap Kwadijk of Delft Hydraulics.

\section{REFERENCES}

[1] Boko MI, Niang A, Nyong C, et al. Climate Change: Impacts, adaptation and vulnerability. Contribution of working group II to the fourth assessment report of the Intergovernmental Panel on Climate Change, Cambridge UK: Cambridge University Press 2007; pp. 433-67.

[2] Hastenrath S, Polzin D, Mutai C. Diagnosing the 2005 drought in equatorial, East Africa. J Clim 2007; 20: 4628-637.

[3] Huntingford C, Lambert FH, Gash JHC, et al. Aspects of climate change prediction relevant to crop productivity. Philos Trans R Soc B 2005; 360: 1999-2009.

[4] Hulme M, Doherty R, New M, Ngara T. African climate change: 1900-2100. Clim Res 2001; 17: 145-68.

[5] Trenberth KE, Jones PD, Ambenje R, et al. Observations: Surface and atmospheric climate change. In: Solomon SD, Qin M, Manning Z, Eds. Climate Change: The physical science basis. contribution of working group i to the fourth assessment report of the intergovernmental panel on climate change. United Kingdom and New York, USA: Cambridge University Press, Cambridge 2007.

[6] Conway D. From headwater tributaries to international river basin: adaptation to climate variability and change in the Nile river basin. Global Environ Change 2005; 15: 99-114.

[7] Funk C, Senay G, Asfaw A, et al. Recent drought tendencies in Ethiopia and Equatorial-Sub-tropical Eastern Africa. Famine Early Warning System, US Agency Int Develop 2005.

[8] Conway D, Hulme M. The impacts of climate variability and climate change in the Nile Basin on future water resources in Egypt. Int J Wat Resour Dev 1996; 12: 277-96.

[9] Tate EL, Sene KJ, Sutcliffe JV. A water balance study of the upper White Nile basin flows in the late nineteenth century. Hydrol Sci J 2001; 46(2): 301-18.

[10] Elshamy MEAM. Improvement of the hydrological performance of land surface parameterization: An application to the Nile Basin. Doctor of Philosophy (PhD) Thesis, Imperial College, University of London, London 2006.

[11] Benestad RE, Hanssen-Bauer I, Chen D. Empirical-statistical downscaling, World Scientific Publishers 2008.

[12] Meiring W, Monestiez P, Sampson PD, Guttorp P. Developments in the modelling of nonstationary spatial covariance structure from space-timing monitoring data. In: Baafi Schofield Eds, Geostatistics Wollongong '96, Kluver, Dordrecht, The Netherlands, 1997; pp. 162-73.

[13] Nakicenovic N, Alcamo J, Davis G, et al. Special Report on Emissions Scenarios, Intergovernmental Panel on Climate Change, 2000.

[14] Gissila T, Black E, Grimes DIF, Slingo JM. Seasonal forecasting of the Ethiopian summer rains. Int J Clim 2004; 24: 1345-58.

[15] Sene KJ, Tate EL, Farquharson FAK. Sensitivity studies of the impacts of climate change on White Nile flows. Clim Change 2001; 50: 177-208.
[16] Kebede S, Travi Y, Alemayehu T, Marc V. Water balance of Lake Tana and its sensitivity to fluctuations in rainfall, Blue Nile basin, Ethiopia. J Hydrol 2006; 316: 233-47.

[17] Conway D. The climate and hydrology of the Upper Blue Nile, Ethiopia. Geog J 2000; 166: 49-62.

[18] Lin B, Day J, Koren V, Markstrom E, Shuzheng C. Precipitation grids in the Nile Forecast System, Office of Hydrology, US National Weather Service 1996.

[19] Abtew W, Obeysekra J, Shih G. Spatial analysis for monthly rainfall in south Florida. Water Resour Bull 1993; 29(2): 179-88.

[20] Teegavarapu RSV. Estimation of missing precipitation records integrating surface interpolation techniques and spatio-temporal association rules. J Hydroinfo 2009; 11(2): 133-46.

[21] Matheron G. Principles of geostatistics. Econ Geol 1963; 58: 124666.

[22] FAO. CLIMWAT for CROPWAT Database, http://www.fao.org/ landandwater/aglw/climwat.stm. United Nations Food and Agriculture Organization, Rome 2000.

[23] Van der Weert R. Performance of the NFS system in simulating water balances, Nile Forecast Center, Ministry of Water Resources and Irrigation, Egypt 2003.

[24] Allen RG, Pereira LS, Raes D, Smith M. Crop evapotranspiration Guidelines for computing crop water requirements - FAO Irrigation and drainage paper 56, FAO - Food and Agriculture Organization of the United Nations, Rome 1998.

[25] IPCC. Climate Change: Impacts, Adaptation and Vulnerability. Contribution of Working Group II to the Fourth Assessment, Report of the Intergovernmental Panel on Climate Change, Parry ML, Canziani OF, Palutikof JP, van der Linden PJ, Hanson, CE, Eds. Cambridge, UK: Cambridge University Press 2007; pp. 976.

[26] Risbey JS, Stone, PH. A case study of the adequacy of GCM simulations for input to regional climate change Assessments. J Climate 1996; 9(7): 1441-467.

[27] Tripathi S, Srinivas VV, Nanjundiah RS. Downscaling of precipitation for climate change scenarios: A support vector machine approach. J Hydrol 2006; 330(4): 621-40.

[28] Frias MD, Zorita E, Fernandez J, Rodriguez- Puebla C. Testing statistical downscaling methods in simulated climates. Geophy Res Lett 2006; 33: L19807.

[29] Timbal B, Hope P, Charles S. Evaluating the consistency between statistically downscaled and global dynamical model climate change projections. J Climate 2008; 23(2): 54-78.

[30] Hewitson BC. Deriving regional precipitation scenarios from general circulation models, Report K751/1/99, Water Research Commission, Pretoria, South Africa 1999.

[31] Widmann M, Bretherton, CS, Salathé EP Jr. Statistical precipitation downscaling over the Northwestern United States using numerically simulated precipitation as a predictor. J Clim 2003; 16(5): 799-816.

[32] Salathe Jr, EP. Downscaling simulations of future global climate with application to hydrologic modelling. Int J Clim 2005; 25: 41936.

[33] Rosenfeld D, Wolff DB, Atlas D. General probability-matched relations between radar reflectivity and rain rate. J Appl Meteorol 1993; 32(1): 50-72.

[34] Hosking JRM. Modeling persistence in hydrological time series using fractional differencing. Water Resour Res 1984; 20(12): 1898-908.

[35] Matheron G. Principles of geostatistics. Econ Geol 1963; 58: 124666.

[36] Mantoglu A, Wilson JL. The Turning Bands Method (TBM) for simulating random fields using line generation by a spectral method. Water Resour Res 1982; 18(5): 1379-94.

[37] Deidda R. Rainfall downscaling in a space-time multifractal framework, Water Resourc Res 2000; 36(7): 1779-94.

[38] Fowler HJ, Kilsby CG, O'Connell PE. A stochastic rainfall model for the assessment of regional water resource systems under changed climatic conditions. Hydrol Earth Sys Sci 2000; 4: 261-80.

[39] Wardlaw RB, Hulme M, Stuck AY. Modelling the impacts of climatic change on water resources. J Chartered Inst Water Environ Manage 1996; 10: 355-64.

[40] Thornthwaite CW. An approach toward a rational classification of climate. Geogr Rev 1948; 38: 55-94.

[41] Nile Forecast Center. NFS Operational Manual: Part (5) Hydrological Modeling of the Nile Basin. Ministry of Water Resources and irrigation, Cairo, Egypt 1999. 
[42] Schaake JC, Koren VI, Duan QY, Mitchell K, Chen F. Simple water balance model for estimating runoff at different spatial and temporal scales. J Geophys Res Atmos 1996; 101(D3): 7461-75.

[43] Nile Forecast Center: Nile Forecasting System software version 5.1, Ministry of Water Resources and irrigation, Cairo, Egypt 2007.

[44] Sayed MAA, Saad B. The experience of the Nile Forecast Centre (NFC) in managing floods and setting strategies for knowledge dissemination, The 18th Congress on Irrigation and Drainage, Montreal, Canada 2002.

[45] Elshamy ME. Assessing the hydrological performance of the Nile Forecast System in long term simulations. Nile Basin Scientific Magazine 2008; 1: 22-36.

[46] IPCC. IPCC Special Report - Emissions Scenarios, Summary for Policymakers, Intergovernmental Panel on Climate Change 2000 [http://sres.ciesin.org/index.html]

[47] Ruosteenoja K, Carter TR, Jylhä K, Tuomenvirta H. Future climate in world regions: an intercomparison of model-based projections for the new IPCC emissions scenarios. The Finnish Environment 644, Finnish Environment Institute 2003; pp. 83.

[48] Yates D, Strzepek K. Modelling the Nile Basin under climatic change. J Hydrol Eng 1998; 3(2): 98-108.

[49] Randall DA, Wood RA, Bony S, et al. Climate models and their evaluation. In: Solomon SD, Qin M, Manning Z, et al., Eds. Climate Change: The Physical Science Basis. Contribution of Working Group I to the Fourth Assessment Report of the Intergovern- mental Panel on Climate Change. Cambridge, United Kingdom and New York, USA: Cambridge University Press 2007.

[50] Giorgi F, Hewitson B, Christensen J, et al. Regional climate information - evaluation and projections. In: Houghton JT, Ding Y, Griggs DJ, et al., Eds. Climate Change 2001: The Scientific Basis. Contribution of Working Group I to the Third Assessment Report of the Intergovernmental Panel on Climate Change. Cambridge and New York: Cambridge University Press 2001; pp. 583-638.

[51] Christensen JH, Hewitson B, Busuioc A, et al. Regional Climate Projections. In: Solomon SD, Qin M, Manning Z et al. Eds. Climate Change: The Physical Science Basis. Contribution of Working Group I to the Fourth Assessment Report of the Intergovernmental Panel on Climate. Cambridge, United Kingdom and New York USA: Cambridge University Press 2007.

[52] Leggett J, Pepper WJ, Swart RJ. Emissions scenarios for IPCC: An update. In: Houghton BA, Callander SK, Varney D, Eds. Climate Change. Supplementary Report to the IPCC Scientific Assessment. Cambridge University Press, Cambridge UK 1992: pp. 69-95.

[53] Riebsame WE, Strzepek, KM, Wescoat R, et al. Complex river basins. In: Strzepek KM, Smith, JB, Eds. As Climate Changes, International Impacts and Implications. Cambridge United Kingdom: Cambridge University Press 1995: pp. 57-91.

[54] Jenkins GJ, Murphy JM, Sexton D, et al. UK Climate Projections: Briefing report. UK: Met Office Hadley Centre, Exeter 2009.

(C) Nawaz et al.; Licensee Bentham Open.

This is an open access article licensed under the terms of the Creative Commons Attribution Non-Commercial License (http://creativecommons.org/licenses/by-nc/3.0/) which permits unrestricted, non-commercial use, distribution and reproduction in any medium, provided the work is properly cited. 